\title{
Urban Social Movements and the Right to the City: An Introduction to the Special Issue on Urban Mobilization
}

\author{
Anna Domaradzka ${ }^{1}$ iD
}

Published online: 20 August 2018

(C) The Author(s) 2018

\begin{abstract}
This paper introduces the special issue and explains the diversity as well as common features of mobilization practices present in cities around the world. The paper starts with presenting the specificity and history of urban movements worldwide, as well as the development of 'right to the city' frame. Drawing on the existing literature, it focuses on presenting different forms of urban activism and interpretations of 'right to the city' slogan. This paper strives to fuse the framework of social movements as networks (Diani, in: Diani, McAdam (eds) Social movements and networks, Oxford University Press, Oxford, pp 299-318, 2003) of challengers (Gamson in The strategy of social protest, Wadsworth Publishing, Belmont, 1990) with the concepts of diffusion and translation of ideas, borrowed from Finnemore and Sikkink (Int Org 52(4):887-917, 1998). It also illustrates the application of the theoretical concepts of incumbents and challengers (Gamson 1990), organizational platform and norm life cycle (Finnemore and Sikkink 1998) as well as the development on movement networks within and between localities (Diani in The cement of civil society: studying networks in localities, Cambridge University Press, New York, 2015). The theoretical model helps to explain the rapid global spread of the notion of the 'right to the city.' The paper concludes with a discussion of the urban context, both 'glocal' and global, as an arena of social mobilization around different aspects of the 'right to the city.'
\end{abstract}

Anna Domaradzka

anna.domaradzka@uw.edu.pl

1 Institute for Social Studies, University of Warsaw, Stawki 5/7, 00-183 Warsaw, Poland
Keywords Urban movements · Grassroots · Mobilization · Right to the city

\section{Introduction}

The interest in urban activism within a broader context of civil society and social movements has been growing steadily in recent years, as a consequence of a new wave of activism emerging in urban settings across the globe. Urban mobilization takes many forms, including traditional civil society organizations (grassroots neighborhood organizations, housing associations, local interest groups, politically or culturally oriented pressure groups), as well as protests initiatives (against profit-oriented urban policies or commercialization of public resources) or political movements for environmental and social justice. As Bitusíková (2015) points out, urban activism has been increasingly considered an important part of urban governance processes as local activists participate in urban politics and influence decision-making through legal tools and participatory practices. While citizen's involvement in governance has gradually come to be seen as one of the crucial factors of democratic and sustainable urban development (see, e.g., Holston 1999; Purcell 2003; Staeheli 2003), it remains unclear which of many urban initiatives should be included in democratic processes and how to compromise between their often conflicting goals.

This paper's objective is to offer an introduction to the special issue on urban mobilization in the times of urban crisis. To this aim, it summarizes and systematizes the differences between urban initiatives as observed in cities worldwide, focusing on the so-called urban movements and the 'right to the city' initiatives. It also attempts to 'unpack' the mobilizing frame of right to the city by illustrating its 
different interpretations or 'facets,' thus allowing for better understanding what 'urban' in 'urban movements' means.

This special issue focuses on the city as both the arena and the subject of social mobilization, illustrating the diversity of approaches and strategies employed by different groups of urban civil society actors. I argue that those different types of grassroots activism can be all understood as a manifestation of the right to the city struggle, as presented by Lefebvre (1968) and developed by Harvey (2008) and Marcuse (2009) to include the context of globalization and consequences of the neoliberal paradigm. This introduction is inspired by the global spread and (at least discursive) success of the 'right to the city' frame, popularized most notably by the Right to the City Alliance in the USA, the Derecho a la Ciudad movements in Latin America, the Recht auf Stadt initiatives in Germany and Urban Movements Congress in Poland.

The cases presented in this special issue are meant to illustrate how cities become a theater of global transformation, including the ways of how people come together, define a common agenda and collectively act to achieve their goals (Diani et al. 2018). Papers presenting data from Czechia, Hungary, Poland and Romania illustrate how, due to a postponed period of post-industrial development, the urban movements in the region emerged later than in the West, but quickly gained momentum. Due to the period of communism that stifled autonomy and strictly regulated all forms of social activism, CEE countries have only recently started to observe the urban mobilization processes that were visible in Western countries since the 1960. Papers focusing on France, Italy or Spain (Catalonia) describe different forms of urban activism, ranging from housing struggles, through artistic appropriation of space, to different forms of social entrepreneurship. Finally, a Cape Town case serves as an example of possible analytical approach to studying the importance of right to the city agenda as a mobilization frame.

In the following, a brief history of urban movements will be presented to explain the existing diversity of forms of urban mobilization. Consecutively, a short overview of right to the city concept helps to systematize its different interpretations or 'facets' present in the field of urban activism. Finally, the introduction offers a review of theoretical concepts that help explain the relative success of right to the city frame and its possible consequences.

\section{The Urban Crisis and Urban Movements}

As a result of the largest wave of urban growth in history, more than half of the world's population now lives in cities and urban problems became central to both policy makers and civil society actors worldwide (Frantzeskaki et al.
2016; New Urban Agenda 2016). While urban development brings huge social, economic and environmental transformations, nowhere is the rise of negative social processes clearer than in urban areas, where enclaves for the rich often coexist alongside ghettos of the disempowered poor.

Therefore, it comes as no surprise that some key social conflicts nowadays concern urban issues and often center on socio-spatial rights and needs. Main areas of struggle include the growing privatization of both services and places (Lorrain and Stoker 1997; Becker et al. 2017); the gentrification processes pushing low-income groups out of upscaling neighborhoods (Beauregard 1986; Smith 1987; Freeman 2009); and the lack of affordable housing and accessible public spaces (Appadurai 2001; Smith 2008; Soja 2010). While a profit-oriented logic is increasingly shaping the cities, they tend to become less livable and less adapted to the residents' needs (Massam 2002; Baohua 2006; Harvey 2008; Marcuse 2013). In the context of this so-called urban crisis, the civil sphere-defined by Alexander as a sphere that is 'analytically independent, empirically differentiated, and morally more universalistic vis-à-vis the state, and the market and from other social spheres as well.' (Alexander 2006: 984) - is where those problems are defined, articulated and, in some cases, resolved. These processes, some argue, led to the emergence of specific civil society actors, namely urban social movements (Castells 1972; Hamel 2014; Fainstein and Fainstein 1974; see also Fincher 1987). Castells perceives these movements as agents of change of the urban system and suggests that mobilization can be explained by the intensity of urban problems and the contradictions behind them (Castells 1972, 1983).

Later, Pickvance (2003) coined the shorter term 'urban movements,' skipping the 'social,' similarly to environmental or women movements. As Pruijt defines them, 'urban movements are social movements through which citizens attempt to achieve some control over their urban environment. The urban environment comprises the built environment, the social fabric of the city, and the local political process.' (Pruijt 2007: 1). As Hamel points out, contemporary urban movements seek social recognition by demanding a 'right to the city' and building democratic and solidarity-based spaces rooted in local cultures (Hamel 2014:466), in opposition to urban development models designed for the elites (Brenner et al. 2012). When integrated, these two definitions offer the most accurate description of urban movements, whose activities range from advocacy and service provision to political representation, as well as down-to-earth problem solving at the neighborhood level.

Traditionally, urban movements were studied as movements happening in the cities-including workers' 
movement, students' movement, etc. However, a more precise definition applies to movements which engage with the city or with urban policies, which are specifically urban at their core, reflecting the problems, needs and lifestyles typical for the urban environment. In recent years, we could specifically observe a rise of collective actions mobilizing around urban planning issues. However, those struggles are usually only the beginning of a longer-term engagement in the field of urban policies, in some cases leading to structural transformation of the urban system.

Castells, in his initial analysis (along the lines of historical materialism), proposed a normative definition of urban movements, seeing in them an actor who is to bring about a thorough social and political change, acting in a coalition with trade unions and political parties (Castells 1972). In the mid-1980s, when there was an intensification and increase in the diversity of urban conflicts, forms of protest and political mobilization, a narrow definition of social movements was replaced by a less normative vision of urban activism. Castells redefines urban movements as 'city-oriented mobilization, affecting structural social change and transforming urban meanings' (Castells 1983: 305) through the pursuit of three goals: (1) realizing collective consumption demands (e.g., related to public services or social housing) through de-commodification and focusing on the city's use value; (2) strengthening the cultural identity and two-way communication instead of top-down information flow; and (3) promoting territorially based self-management and autonomy of local communities. Following in Castells footsteps, the definition used by researchers usually ignores the political engagement of urban movements, focusing on the values to which they refer, like democracy, justice, equality, etc. The contributions of the SI will show that while 'urban issue' becomes increasingly political, so are some of the movements striving to gain real control over cities power structures, running in elections and expressing explicit political programs.

\section{The Urban Context as the Arena of Right to the City Mobilization}

With the increased mobility that has accompanied globalization, cities have become main venues of social and political transformation. Main urban centers are situated within transnational networks of economic and cultural exchange, which turned them into strategic spaces for the global economy, but also arenas where the diversity (or what Tasan-Kok et al. 2014 call 'hyper-diversity') challenges traditional ideas of citizenship and fosters new citizenship practices and identities (Sassen 2002). While different authors have pointed out that anonymity and alienation are typical traits of urban lifestyles (Simmel 1903; Beck 1992; Castells 1983), mushrooming grassroots initiatives seem to prove that the urban environment can be a fertile ground for new as well as traditional forms of civic engagement. Rooted in-between the private and public spheres, urban activism grows from concrete challenges like density, diversity and an imbalance of power among urban stakeholders. These stimulate the development of a specifically urban civil sphere as described by Alexander (2003), including place-oriented, democracy-oriented as well as 'quality of life'-oriented forms of social engagement and collective action. What seems to be at their core is the question: 'what type of city we want to live in?' It embodies opposition to the general trends of privatization of public spaces and housing, socio-spatial segregation and residents' lack of access to decision-making influencing their everyday life.

To explain recent cycles of urban contention we should look into both objective and subjective mobilizing factors. On the objective level, we can observe how many modern cities became 'capital production hubs' and 'growth engines' (see Nawratek 2017; Colenbrander 2016; Vliet 2002), with the economic interests and the logic of profit dictating the direction of urban development. This means fewer investments in social infrastructure and more in 'hard' infrastructure that would attract new investors, also, more incentives and flexibility in terms of allowing construction in areas that had recreational, environmental or communal value. The willingness to please big investors was particularly important in post-industrial cities, struggling to bring in new employers, as well as cities in the global semiperiphery, striving to catch up with the First World's rate of development and willing to offer cheap land, workforce and special deals to big market players. In CEE countries where the period of transformation was characterized by relative poverty after years of communistic regime, foreign companies enjoying the privileges of 'first movers' quickly filled the investment vacuum. As a result of unregulated spatial development, fueled by a post-communist housing hunger, the region started to experience the classic suburbanization processes, in, e.g., Poland also followed by excessive trend of gating housing estates. As in Western countries, rapid urban growth created new environmental challenges (air pollution, noise pollution, etc.) and put too much strain on the social services system that was designed to serve smaller and less diverse populations. To summarize, we can say that, in some of the cities and many of the neighborhoods, a visible decrease in terms of quality of life could have been observed, raising valid concerns among the residents (Harvey 2012; Jacobsson 2015; Mergler 2008).

However, the negative change in terms of life standards was hardly enough to create wider mobilization. Following 
the analyses of Castells, Hamel and Mayer, I will argue that to understand the consecutive waves of urban contention it is necessary to study the cultural shifts as well as identity processes that allowed for successful framing of collective goals and new norms. What made the ideas of 'right to the city' or 'city for all' so carrying is connected to several factors, including: (1) new media enabling the spread of information and exchange of know-how between geographically distant actors; (2) glocalization processes (Robertson 1992; Massey 1994) that focus on local environments as a response to globalization-related weakening of identity and sense of belonging; (3) social and environmental deterioration threatening the quality of life of all, pushing into action diverse groups of residents, including middle class and intelligentsia, whose voice resonates in the public debate. Different forms of urban mobilization, united under the right to the city umbrella, are an example how solidarity can be generated through skillful framing and introducing new norms via dominant cultural codes. As Alexander suggests (2006), the role of media in producing wider social solidarity and enabling new waves of urban contention is crucial.

Following the work of Tasan-Kok (Tasan-Kok et al. 2014), Beck (2000) and Bauman (2006) we can single out the role of urban activism as a source of identity and sense of belonging for urban dwellers, replacing the weakening traditional support structures (based on extended family and tight community ties), in neighborhood networks and supra-local alliances of like-minded activists. In the era of increased mobility and shrinking families, we could interpret the growing interest in the semi-public and public space as well as neighborhood relations as a sign of socioeconomic transition, focused on creating new placebased or lifestyle-based communities. As several authors show (Di Masso 2012; Domaradzka 2015; Flesher Fominaya 2015) the need for 'new community' and 'reference group' is one of the reasons fueling many forms of urban mobilization, including neighborhood groups' initiatives or activity of local associations. Interviews with local activists illustrate how the idea of 'my home is my castle' is being replaced by 'my neighborhood is my business,' with place attachment processes (Lewicka 2011) very much at play. This also reflects Lefebvre's 'right to the city' idea, underlining the importance of transforming urban space into a meeting point for building collective life, with the citizen at the center as main element and protagonist of the city.

\section{A Brief History of Urban Movements}

Although the notion of 'urban social movement' appeared already in the literature in 1972 (Castells 1972), social movements and collective action around central urban issues such as housing or rights of the city dwellers date back to as far as the late nineteenth century (Lawson 1988). However, the sociological analysis (Mayer 2007; Marcuse 2009; Hamel 2014) focuses mainly on recent waves of mobilization of urban movements in the Western countries of the global core (Wallerstein 2004). As Jacobsson puts it, 'urban movements in Central and Eastern Europe (CEE) have to a large extent remained a blind spot in international urban movement studies' (Jacobsson 2015: 273). Recently, two edited volumes by Jacobsson (2015) and Sava (2015) presented the variety of urban grassroots in several CEE countries, illustrating both differences (such as the more diverse and ad hoc character of urban initiatives in CEE as compared to elsewhere, see Jacobsson 2015: 273) and similarities (use of same narratives and slogans) of the regions' mobilization in comparison with the mainstream analysis.

Despite its Western focus, the descriptions of consecutive waves of urban mobilizations presented by Mayer and Hamel remain relevant worldwide, as they explain the present heterogeneity of the movement. The authors date the first wave of urban mobilization in the 1960s and associate it with the crisis of Fordism. Characteristic of this period were the conflicts around housing, strikes against rent increases and campaigns for urban renewal in the face of segregation, suburbanization and the growth of 'inhospitable cities' (Mitscherlich 1965). The radical slogans like 'Let's take the city' were voiced primarily by young people, students and migrants in Western Europe. In the USA, in turn, the pragmatic ideas of regaining control over the local community (the so-called community control, see Fainstein and Fainstein 1974) were predominantly proclaimed, especially among the African-Americans. It was also a period when protests moved from factories to housing estates, focusing on matters related to access and quality of public services and infrastructure, generating local initiatives and alternative solutions to existing problems.

The next phase in the history of urban social movements was, according to Mayer (2007), the effect of the 1980s policies of budgetary cuts in public spending, and the increasing importance of the neoliberal paradigm, at the expense of the welfare state institutions and the sociocollectivist model (mainly visible in European countries).

The search for alternatives, especially innovative ways of providing services and coproduction of public goods (Brandsen et al. 2018), has opened up opportunities for 
cooperation between the authorities in many Western countries and local organizations. The change of the relationship from confrontational to cooperative was conducive to the development of specific types of serviceoriented urban movements that contributed to the improvement of the quality of life of residents, but also increased the legitimacy of local authorities. As a result, many urban organizations have shifted 'from protest to program,' filling the gaps in the public services system, that in turn ensured them with a relative financial stability.

A similar 'wave' appeared in CEE Europe several years later, following the fall of communism and the opening of their markets to the capitalist logic. In the face of growing unemployment, poverty, housing needs and the associated social dissatisfaction, local authorities have begun to seek new ways of solving social problems. Urban activists' transition from the logic of protest to the logic of a subcontractor-which some researchers also call the 'NGOization of civil society' (Korolczuk 2011; Jacobsson and Saxonberg 2013) — was very much visible in the CEE countries, which in the 1990s went through the accelerated scenario of civil sector professionalization (Polanska 2011; Schreier 2016).

Worldwide, the growing professionalization and institutionalization of some urban movements (thus distancing themselves from the radical postulates) generated cleavages in the urban movement environment, as many emerging initiatives were critical of co-optation and routinization of local organizations activities. This bifurcation of the urban activism strengthened the mobilization of the city's middle class, whose representatives were involved in both progressive (ecological, feminist, anti-war) and conservative (reactionary or NIMBY) activities (Mayer 2009: 365). As a result of the second phase of changes, increasingly diverse and fragmented forms of urban protests began to coexist in cities, and the urban movement environment lost the ability to interact or even express common postulates.

The third stage or 'wave' of urban mobilization can be dated back to 1990s, when as a result of the increasingly intense implementation of market mechanisms in the public sphere, fueled by the New Public Management approach, cities began to function as engines of economic growth, competing with each other for investors and consumption leaders. During this period, local authorities began using the achievements and slogans of urban initiatives to promote the image of a 'creative city' and strengthen its competitive advantages. Active local communities, places of protest and resistance, have been labeled as attractive landmarks of the city-a mosaic of alternative subcultures, spaces and initiatives (Novy and Colomb 2013; Gurr 2017; Thörn 2012; Inal and Gezgin 2017). The use of slogans and energy of urban movements to strengthen the economic potential of the cities have led to further fragmentation of bottom-up initiatives. At the same time, they provoked the discussion around 'whose city is it?' (Sassen 1996) and the growing politicization of the 'urban issue,' accompanied by waves of alter-globalist demonstrations and protests concerning gentrification, under the slogans of 'Reclaim the Streets' and 'Another city is possible!' (Mayer 2009: 365).

According to several authors (Hamel 2014; Mayer et al. 2016; Andretta et al. 2015), the early 2000s mark the next stage of urban change and movements mobilization. Apart from the increasing professionalization of local organizations, three new trends of urban mobilization and opposition to the policy of growth began to emerge simultaneously. First were the protests against the commercialization of public spaces, the intensity of supervision (police activities and presence of security cameras) and cities' marketing strategies in the context of the deteriorating situation of some districts and neighborhoods. The second trend represented primarily the interests of the urban precariat (Johnson 2011), and the unemployed, often combined with the demands for social and spatial justice in terms of protection of workers' and immigrants' rights (Ranci et al. 2014; Della Porta 2015). The third trend was the transnational activity of anti-globalist movements, demanding the democratization of international institutions, but also access to urban public goods and services. This contributed to the popularization of the slogans of urban movements around the world in a form of norm cascade (Finnemore and Sikkink 1998) and further institutionalization of 'right to the city' norm (see, e.g., New Urban Agenda 2016).

As a result, in the last years, we can observe the development of a global network of organizations and initiatives representing the rights of residents (such as the Social Forum, Attac or Future of Places), guided by slogans of spatial justice and residents well-being. At the same time, global demands for democratization are translated into the local context and actions of urban movements (see, e.g., Andretta et al. 2015; Domaradzka 2017; Hou and Knierbein 2017). As Mayer points out, although the "city neoliberalization' has created an environment hostile to progressive urban movements, it also enabled them to articulate urban protest, and gave birth to coalitions joining various strands under the joint umbrella of the right to the city (Mayer 2009: 367).

While the processes of global networking continue until today, one may posit that the urban movements are entering a fifth phase of localization, associated with politicization in the form of local election committees, with leaders of urban initiatives becoming part of local power structures (e.g., in Barcelona, Warsaw or Poznan). It is a phase that creates new challenges, as it promotes the 
fragmentation and co-optation of urban movements by the ruling parties, often leading to delegitimization of activists' claims. However, history suggests that, as long as urban policy fosters social inequalities and excludes large numbers of citizens, the slogans of the right to the city retain the ability to mobilize bottom-up initiatives. However, one can expect negative consequences (like the delegitimization or breakup of urban movements already visible in Montreal, see Hamel 1986; recently also Poland, see Author 2017; for Turkey, see Özdemir and Eraydin 2017) of activists entering local politics and the discrediting of urban slogans as a result of the political compromises.

As in the case of other social movements (e.g., women's or ecological movements), urban movements from the very beginning have had the character of a multi-level network combining various forms of urban involvement, such as grassroots neighborhood initiatives, protest groups or local associations. As shown by the historical analyses, over time the level of diversity and complexity of this network increased, and its composition was dynamically changing with the transition of some organizations from the area of civil society to the field of public services or party politics and the emergence of new allies (like squatter movements and tenant associations). As a result of its liquid and multilevel character, operating as a loose network of organizations, initiatives and individual actors function now both on the global level, and in individual cities and even local communities. In some cases, also national or regional urban movement platforms operating at the meso-level are emerging, as is the case with the Congress of Urban Movements in Poland (Domaradzka 2018), Right to the City Alliance in the USA (Sinha and Kasdan 2013) or Plataforma de Afectados por la Hipoteca movement in Spain (Santos 2018).

Typically, the first impulse to formulate an urban movement initiative was to organize a protest against the existing policies (e.g., causing mass evictions) or development plans (e.g., replacing communal or recreational spaces with private investments). The grassroots groups of protesters soon realized that their opposition had limited effectiveness and that real impact would require the introduction of social consultation mechanisms and participatory planning tools (see, e.g., Mergler et al. 2013). Searching for support for such solutions has contributed to the formation of wider coalitions between activists from different districts or cities to change the rules of decisionmaking processes. At the same time, however, more radical groups appeared in the cities, contesting marketing efforts of local governments, through actions aimed at reducing the attractiveness of cities-emphasizing existing problems, conflicts or hidden enclaves of poverty and exclusion. So from the one hand, radical movements focused on active resistance and disruptive behavior to challenge the status quo, while milder activities of the middle class or the intelligentsia groups focused on abstract issues related to the privatization of public space and right to self-expression. As Mayer points out, the latter protests are often short-lived and focus on creative expression of views rather than effective resistance, which means that they remain in the area 'between protest and carnival' (Mayer 2007: 97). Those activities are often hijacked by the economical and political elites who like to incorporate the urban struggles into 'creative city' branding. By building an official narrative about the city diversity, 'rebellious spirit' and openness to alternative lifestyles (Uitermark 2004; Novy and Colomb 2013) those elites hope to attract tourists and big companies looking for attractive locations. What is more, as the campaigns against the privatization of public and political space are becoming a topic for intellectuals and cultural activists with limited outreach, the remains of wider movements become increasingly isolated and compete with each other for the small residual resources and spaces.

\section{'Right to the City' as a Common Frame}

The slogan of the right to the city, though intuitively understandable and extremely fashionable in recent years (De Souza 2010), is a complex concept requiring a theoretical analysis. Following Harvey (2008), I will define it here as both the individual liberty to access urban resources (including space, services and infrastructure) and the ability to exercise a collective power to reshape the processes of urbanization.

The work of Henri Lefebvre was crucial in crystallizing the contemporary understanding of the right to the city-in Le Droit à la Ville (1968) he described it as both 'cry and demand,' later adding that it is in fact a conglomeration of various rights, including the right to information, access to services, to operating in urban space, to using the city center (Lefebvre 1991: 34). The distinction between 'cry' and 'demand' suggests, according to Marcuse (2009), that the right to the city expresses both the protest of excluded groups (homeless, poor, hungry or persecuted), and the aspirations of groups that, although integrated in the existing system, are not able to realize their full potential. The first group consists of excluded social groups and lowpaid working class. The second group includes the alienated representatives of middle and high classes, especially young people, small entrepreneurs, representatives of the intelligentsia, artists and officials. Ultimately, the source of 
the frustration of both groups is that the city services and initiatives do not meet their important needs.

According to critical urban theorists (Marcuse 2009; Mayer 2009; Brenner et al. 2012), currently the right to the city (here understood mainly as control over its resources) is attributed primarily to a group of economically and politically privileged, represented by the elite of the real estate market, influential politicians and media owners. Those incumbents often trigger mechanisms that can dissipate this dissatisfaction of actors deprived of the right to the city by arousing emotions around moral issues, fueling nationalism, homophobia, fundamentalism or chauvinism, and even sports fanaticism that weakens the mobilization potential of right to the city. Despite these commonly occurring 'distractions,' we are now dealing with various forms of civic activity (groups, coalitions, federations, networks, movements and assemblies) mobilizing around the common pursuit of the right to the city in opposition to capitalist logic influencing urban policies. In Benford and Snow's (2000) terms, the slogan of the right to the city became a common conceptual framework for these diverse groups, enabling mobilization around an alternative vision of the cities' future. Both Harvey (2008) and Mayer (2009) refer to the concept of the right to the city as both a political ideal and a mobilization frame. As Soja points out, the right to a city is not only legislative, but also moral, referring to human rights as well as the concept of social and spatial justice (Soja 2010). The values that such a city should embody are justice, the rule of law, democracy, capacity development, as well as balance and diversity (Marcuse 2009: 193).

Analyzing the changing slogans and forms of collective action in North and South America and Western, Central and Eastern Europe, we can see the relationship between the meanings given to the right to the city and the dominant forms of exclusion and oppression prevailing in a given period. Presenting the right to the city in opposition to the capitalist order is one of the leitmotifs of the literature on the subject. Most authors remain critical of the dominance of the capitalist system (or neoliberalism), pointing out that its mechanisms exclude large numbers of citizens and thus prevent the democratization of cities (Swyngedouw 1997; Smith 1995; Purcell 2003; Brenner and Theodore 2002). As Marcuse points out, "most problems have a spatial aspect, but their origins lie in economic, social, political arenas, the spatial being a partial cause and an aggravation, but only partial' (Marcuse 2009: 195).

Therefore, authors claim, it is necessary to strive for the ideal of a 'city for people, not for profit' by regaining individual sectors of life from the dominance of the market by, for example, increasing the role of the state and civil society in areas related to health protection, education or culture. As Harvey and other authors point out (Harvey
2008; Nawratek 2012; Smith 2008; Soja 2010; Appadurai 2001), rejecting the logic of profit ${ }^{1}$ is the only way to seek solutions that serve a decent life and create a supportive environment for inhabitants.

While Marcuse and Harvey treat the slogan of the right to the city as a moral postulate referring to ethical principles and values such as justice or goodness, it must be noted that urban movements interpret the slogan in different ways. Some are based on the original concept of Lefebvre, according to which urbanization involves a negative (controlled by the logic of profit) transformation of human life, which must be opposed by lobbying for new methods of city management. In their view, the right to a city is the right to redistribute resources, primarily to those who are deprived of privileges and whose basic needs are not met. This revolutionary version of the right to the city, whose roots Lefebvre sought in the protests of 1960s, is now represented by the actions of Right to the City Alliance in the USA and similar networks in countries around the world (Derecho a la Ciudad movements in Latin America or Plataforma de Afectados por la Hipoteca in Catalonia). This approach opposes the existing allocation of resources and the dominance of the rules of the market in areas such as housing, employment, social services or planning. Networks on regional or national level are developed to create lobbing platforms that not only express alternative vision of city development, but also embody the preached values in their practice, through, e.g., horizontal management, members' empowerment and gender equality.

Other movements interpret the right to the city less radically, using it as a general claim for developing urban democracy, involving residents in decision-making processes and focusing on quality of life in urban areas (see, e.g., Congress of Urban Movements in Poland). Mayer underlines the growing popularity of this second interpretation, promoted by international human rights organizations, such as the UN (UN Habitat program) and UNESCO (2006). In 2003, a team of international organizations presented 'World Charter for the Human Right to the City,' and in 2005 the World Charter on the Right to the City was formally adopted during the Second World Urban Forum in Porto Alegre.

According to the World Charter provisions, the right to the city is a conglomerate of specific laws such as the right to housing, social assistance, work, a decent standard of living, leisure, information, association, access to food and water, participation and auto-expression, health, education,

\footnotetext{
${ }^{1}$ However, the growing popularity of social entrepreneurship or social economy brings in the question of how profit oriented can some of the urban initiatives become, while still remaining part of urban mobilization.
} 
culture, privacy, security, etc. The goal of such defined right to the city is to lobby for policies and legislation that would connect the development of cities with social justice. The documents define a list of specific rights that these policies should protect, combining human rights with the obligations of local and national authorities.

Critics (see, e.g., Eide 2016; Earle 2016; Caprotti et al. 2017) of the above-mentioned international documents draw attention to the fact that their recipients are primarily local authorities, interested in implementing the principle of good governance, using tools such as participatory budgets, transparent management methods and participative decision-making. Although certainly useful, the tools themselves do not affect the essence of the problem of uneven distribution of power. Also, as Mayer (2009) points out, the problem with their general category of urban residents is that it assumes the existence of a relatively cohesive civil sphere that requires protection against the effects of liberal policies. It denies the class divisions and differences in access to power between actors of urban civil society, some of which are beneficiaries or even cocreators of the 'machine of the economic growth.' In other words, the definition of right to the city popularized by transnational organizations calls for more inclusion within the existing system, without offering a vision of changing the current development model.

The result of those new documents is paradoxical-the slogans and postulates of grassroots urban movements are on the one hand strongly supported by the involvement of international institutions such as the United Nations; on the other hand, the same commitment deprives these slogans of inspiration for a deeper social change. Bottom-up pursuits are institutionalized as part of a professional NGO network, appearing as a body representing the needs of all city dwellers and supporting the cooperation of these residents with local authorities for sustainable development.

Moreover, as a result of the growing professionalization and politicization of urban initiatives in some of the cities (e.g., Barcelona, Montreal, Prague, Warsaw, Poznan) incumbents groups started to employ right to the city frame, modeling their political programs on the urban movements manifestos. Recent interviews with developers (Domaradzka 2018; unpublished) illustrate how even the private actors claim their right (to profit) from the city. This hijacking of the urban movements slogans creates new challenges in terms of common narrative, but also signifies 'a norm cascade' described by Finnemore and Sikkink (1998).

The right to the city also remains alive and radical among the diverse groups of activists for global justice, both on the local level and transnationally. As Mayer notes, as part of these local symptoms a new form of urban mobilization emerged: a new local actor has emerged for whom broad coalition building and a new kind of advocacy professionalization are characteristic. Media-savvy, organizationally conscious activists are connecting the political agendas of citizens initiatives, social service organizations, and a variety of social movements and NGOs, as well as church organizations, in an explicit effort to overcome the segmented local patterns of protest and to build organizational continuity. As with the transnationally active movements before them, they combine traditional repertoires built up during previous cycles of protest with new tactics of civil disobedience and flexible organizational formats, but apply them to local manifestations of the global neoliberal trends (Mayer 2007: 108).

To summarize, in different national contexts described in this issue, we could observe the convergence of numerous local groups into coalitions and alliances around a shared set of objectives, which see current urban practices as the common problem and the right to the city as a common cause. Many of urban initiatives emerge in order to protect a certain space or place, like in case of heritage protection groups, but also schools, cultural or social centers, squats or important workplaces. Those coalitions include formal actors like nationwide networks of local associations engaged in changing the power balance in their cities to give more voice to residents and their concerns, and organizations fighting for affordable housing and the protection of tenants' rights (Jezierska and Polanska 2017; Grazioli and Caciagli 2018; Florea et al. 2018). However, numerous less formal initiatives celebrating the urban commons as well as more embedded estate councils and traditional contestants, including squatters' movements and alternative cultural spaces, also become allies. Another interesting hybrid form of social engagement that often supports right to the city claims is urban social entrepreneurs (engaged in solving specifically urban problems like lack of access to fresh and healthy food, offering spaces for start-ups, bringing skills and services into dilapidated neighborhoods) focusing on generating profit through pursuing social goals and community-embedded impact (Bilewicz and Potkanska 2013; Bilewicz 2015; Domaradzka et al. 2018, unpublished; Zabłocka-Bursa and Praszkier 2012). Finally, the diverse Not-In-My-Backyard protest groups (who perceive certain investments in their neighborhood as a threat to residents' quality of life) as well as land owners worried about their property value also use the right to the city frame to support their claims.

To better illustrate the multifaceted character of right to the city frame, Table 1 presents a simple typology of urban initiatives organized by different facets of right to the city around which they mobilize. 
Table 1 Different aspects of right to the city and groups mobilizing around them

\begin{tabular}{|c|c|c|c|c|c|}
\hline $\begin{array}{l}\text { Economic and social } \\
\text { rights }\end{array}$ & Housing rights & $\begin{array}{l}\text { Civil and political } \\
\text { rights }\end{array}$ & Environmental rights & Cultural rights & Ownership rights \\
\hline \multicolumn{6}{|c|}{ Different facets of the right to the city mobilization } \\
\hline $\begin{array}{l}\text { Social entrepreneurs } \\
\text { Precarious workers } \\
\text { Trade unions } \\
\text { Unemployed } \\
\text { Marginalized poor } \\
\text { Community-based } \\
\text { organizations } \\
\text { Self-managed social } \\
\text { centers }\end{array}$ & $\begin{array}{l}\text { Housing activists } \\
\text { Tenants' associations } \\
\text { Squatters } \\
\text { Grassroots housing } \\
\text { initiatives }\end{array}$ & $\begin{array}{l}\text { Right to the city } \\
\text { federations } \\
\text { Local election } \\
\text { committees } \\
\text { Advocacy groups } \\
\text { Estate councils } \\
\text { Watchdog initiatives }\end{array}$ & $\begin{array}{l}\text { Environmental groups } \\
\text { Ecological organizations } \\
\text { Food cooperatives } \\
\text { Commoning and sharing } \\
\text { initiatives }\end{array}$ & $\begin{array}{l}\text { Neighborhood } \\
\text { associations } \\
\text { Ethnic and religious } \\
\text { groups } \\
\text { Alternative cultural } \\
\text { spaces } \\
\text { Intercultural centers } \\
\text { Heritage } \\
\text { conservation } \\
\text { groups }\end{array}$ & $\begin{array}{l}\text { NIMBY groups } \\
\text { House owners } \\
\text { Home-owner } \\
\text { associations } \\
\text { Private investors }\end{array}$ \\
\hline
\end{tabular}

Source: own compilation

As the papers included in this special issue illustrate, the slogan of the right to the city became a common conceptual framework (Benford and Snow 2000) for activist groups around the globe, enabling mobilization around an alternative vision of the future of cities (Mayer et al. 2016). Despite all differences, most of the right to the city activists agree in their criticism of the liberalization of markets. Unlike previous generations, however, modern urban activists do not seem to be planning a revolutionary takeover of power, but are working to weaken profit-oriented logic in a pragmatic, concrete and gradual way.

\section{Theoretical Approach}

A wide range of research methods and theories were applied to the study of urban civil society actors (Mayer and Boudreau 2012). While in the 1970s researchers were mainly interested in mobilization concerning renewal projects (Olives 1972) and urban politics in 1980s (Harris 1987), during the 1990s and 2000s they turned toward gentrification and its detrimental effects (Hackworth 2002; Franzén 2005). In recent years, the issue of citizenship and residents' rights (Di Masso 2012) as well as the transnational aspect of the urban movements are getting most academic attention (see Hamel et al. 2000; Jacobsson 2015; Mayer et al. 2016).

Authors working on urban movements drew on the classical theories of social movements (Diani 1992; McAdam et al. 2004), new social movements (Offe 1985), protest analysis (della Porta 2015), critical urban studies (Harvey 1973; Marcuse 2009; Soja 2010), social network theories (Diani 2003) and field theory (Martin 2003; Fligstein and McAdam 2012; Domaradzka and Wijkström 2016).

While analyzing the history of urban movements, this paper combines several theoretical concepts to allow for a better understanding of urban mobilization phenomena and their actors. First, it fuses the framework of social movements as networks (Diani 2003) grounded in localities (Diani 2015) with the concepts of diffusion and translation of ideas, borrowed from authors like Finnemore and Sikkink (1998), Strang and Soule (1998) and Sahlin and Wedlin (2008). Diani's approach to social movements as a distinct form of network organizing (Diani 1992, 2003, 2015) allows viewing urban movements as systems of relations between local groups as well as their environment. This approach is useful for studying urban civic networks in cities (Diani 2015; Diani et al. 2018) and for comparing localities, illustrating their specificity through the lens of network structure and actors' positions within it. The mechanisms of network emergence can be illustrated by Finnemore and Sikkink (1998) concept of organizational platforms, playing the role of network hubs and stabilizing structure. In turn, Strang and Soule (1998) observations concerning the ideas' diffusion in social movements, as well as Sahlin and Wedlin concept of ideas translation and editing mechanisms, find confirmation in the analysis of right to the city trajectories in urban movements narratives (Pluciński 2018; Domaradzka and Wijkström 2016).

The network approach to urban movements profits from merging it with the idea of 'challengers' and 'incumbents' offered by Gamson (1990). Gamson's approach helps to position urban activists in the field of urban policy as it highlights the importance of being either inside or outside of the existing power structures of the field (Gamson 1990). It also positions them vis-à-vis power-holding elites, who play the role of incumbents in the so-defined field. In cases presented in this special issue, urban activists play the role of challengers in their local policy fields, as they focus on contention of an existing order and resistance to mainstream rules, in search of an opportunity to reshape urban 
power structures or more generally the direction of urban development. To understand different forms and results of urban movements engagement Tilly's (1978) concept of opportunity structure can be also employed. As cases presented in this issue illustrate, both opportunities and threats, defined by local sociopolitical context, are distinct catalysts of urban challengers' mobilization.

Apart from the locally defined opportunity structure, however, we can also point out to the emergence of transnational debate about the right to the city as an important impulse facilitating the mobilization of urban activists in different localities. This ideological frame, borrowed from Lefebvre by Right to the City Alliance, quickly gained momentum and became a global reference point to geographically scattered local urban initiatives. At this point, the Finnemore and Sikkink (1998) ideas of institutional platforms and norms' 'life cycle' help to explain the activists' institutional strategies as well as the growing resonance of the right to the city slogan. Their theory also describes a specific type of challenger called 'norm entrepreneur,' an agent who has a decisive role in the first stage of new norm development, often carrying and reshaping a new paradigm or set of ideas between different movement or cultural settings (Strang and Soule 1998). The first stage of norm life cycle is norm emergence, when norm entrepreneurs are motivated to adopt a norm, either by altruism, empathy, or ideational commitment. Norm entrepreneurs often use organizational platforms (Finnemore and Sikkink 1998)_either already existing ones or created specifically for a cause-as tools to promote the new norms and to persuade others (often governments or other public sector actors) to adopt them. Those organizational platforms often have a form of a CSOs federation, as in case of US Right to the City Alliance or Polish Congress of Urban Movements (multi-city coalition) or more loose activists coalitions, such the Derecho a la Ciudad or Recht auf Stadt local networks.

As Finnemore and Sikkink (1998) point out, when enough actors are convinced, the stage of norm cascade begins, during which multiple actors are motivated to adopt a norm in order to enhance legitimacy or reputation. This includes politicians, other activists, international organizations, etc. On the global level, it was reflected by UN Habitat adopting the right to the city claim in the official New Urban Agenda as well as the European Union including it in the Urban Agenda for the EU (2016). The final stage of the norm life cycle is internalization, where the bureaucratic procedures, the legal system and professional training incorporate the norm so it becomes part of common knowledge.

The norm life cycle model describes the surprisingly rapid spread of the right to the city idea in different cities around the globe, including Miami and Los Angeles, Berlin and Hamburg, Río de Janeiro and Porto Alegre, Warsaw and Poznan, and later included in globally discussed of the World Charter for the Right to the City 2005 and the UN New Urban Agenda (2016). For example, in cases such as Brazil and Poland the norm cascade resulted in the institutionalization of the urban movement claims in the local policy setting (Estatuto de la Ciudad de Brasil 2001; Polish Urban Policy 2014). More importantly, the model is useful to detect and explain the ongoing shift in local city administration practices, including the adoption of participatory budgeting, consultation mechanisms and new communication strategies by the cities officials, as a response to the 'glocal' urban activists' pressure (Robertson 1992), which is an issue often overlooked in the analysis of urban movements practices (Domaradzka 2015, 2016). Although, in the case of the right to the city agenda, ongoing institutionalization may reflect the norm's relative 'success,' it also weakens its mobilization capacity and enables it to be hijacked by the elites.

\section{Conclusions}

The complexity of the urban reality is reflected in the complexity of urban movements and forms of protests, adapting to specific places, scales and context. According to Meyrowitz (2005), we live in 'glocalities'-each of them unique, yet reciprocally influenced by global trends. This explains how many localized efforts of neighborhood activists become 'glocalized,' producing a heterogeneous environment of urban mobilization (Gobo 2016). Interestingly, as post-industrial cities are becoming urban regions (Vogel and Savitch 2012), the collective action generated by urban movements begins to spread geographically, covering wider areas and addressing both environmental and other spillover effects of urban centers. However, at their core, urban movements remain locally based and focused on the particular needs and conflicts, which gives them fuel for continuous contention. This approach has been criticized (Fainstein and Hirst 1995) as limiting the movements' claims, but recent developments in several countries seem to prove that this is no longer the case, as local challengers raise to create supra-local coalitions (Flesher Fominaya 2015) and even national networks (Domaradzka and Wijkström 2016) aiming at a more profound change in urban policies.

The rapid changes related to the weakening of the state and the economic crisis create a new opening for the radical interpretation of the right to the city, as the demand for the democratization of cities and changes in decisionmaking practices resonates stronger than before. Although challenging, the changes connected with the refugee crisis and the intensification of various social conflicts may be 
conducive to the implementation of alternative models of urban development. However, in the pursuit of politicizing the crisis, urban movements need to act cautiously and systematically, building social legitimacy, while simultaneously lobbying for the democratization of cities.

This special issue starts with four papers addressing the idea of right to the city directly and then moves on to discussing diverse housing struggles, ending with a piece on social entrepreneurship. The first article by Eynaud, Juan and Mourey analyzes a case study from France to describe participatory art activities as urban commons practice that allows participants to exercise the collective right to the city. The second paper by Diani, Ernstson and Jasny applies a network analytic approach to the role of right to the city as a symbol and a broader frame, to understand the patterns of relations between CSOs in Cape Town. The subsequent paper by Pluciński applies the altermodernist perspective to analyzing the voices of Polish urban activists, constituting both local and national 'urban public sphere.' The paper by Pixova explores the potentials and limits of activists' efforts to improve urban politics and local development in five Czech cities. The paper by Jezierska and Polanska casts more light on the processes of collective claims and identity formation in Polish tenants' movement by applying the theory of radical politics to movement analysis. The paper by Grazioli and Caciagli presents the case of Roman housing rights movements, their role in developing practice of grassroots urban regeneration and their evolution toward polycentric political actors. Another take on housing struggles is presented by Florea, Gagyi and Jacobsson in their paper on Bucharest and Budapest, advancing the relational approach to urban mobilization and laying emphasis on different forms of urban collective actions and their relationship-building capacity. The final paper by Molina, Valenzuela-Garcia, Lubbers, Escribano and Lobato discusses the dynamic of the social entrepreneurship field in Catalonia during the crisis, to illustrate how different actors shape values and practices of those environmentally or socially focused organizations.

Funding This study was funded by the Polish National Science Centre under Grant DEC-2013/09/D/HS6/02968, financing the research project 'City revival - from urban planning to grassroots initiatives' (2014-2017).

\section{Compliance with Ethical Standards}

Conflict of interest The author declares that she has no conflict of interest.

Open Access This article is distributed under the terms of the Creative Commons Attribution 4.0 International License (http://crea tivecommons.org/licenses/by/4.0/), which permits unrestricted use, distribution, and reproduction in any medium, provided you give appropriate credit to the original author(s) and the source, provide a link to the Creative Commons license, and indicate if changes were made.

\section{References}

Alexander, J. (2003). The meanings of social life: A cultural sociology. Oxford: Oxford University Press.

Alexander, J. (2006). The civil sphere. Oxford: Oxford University Press.

Andretta, M., Piazza, G., \& Subirats, A. (2015). Urban dynamics and social movements. In D. Della Porta \& M. Diani (Eds.), The Oxford handbook of social movements (pp. 200-215). Oxford: Oxford University Press.

Appadurai, A. (2001). Deep democracy: urban governmentality and the horizon of politics. Environment and Urbanization, 13(2), $23-43$.

Baohua, L. L. G. (2006). A study on the theory of the livable city. Urban Studies, 2, 16.

Bauman, Z. (2006). Liquid times: Living in an age of uncertainty. Cambridge: Polity.

Beauregard, R. A. (1986). Urban form and the redevelopment of central business districts. Journal of Architectural and Planning Research, 3(3), 183-198.

Beck, U. (1992). Risk society: Towards a new modernity. London: Sage.

Beck, U. (2000). What is globalization?. Oxford: Polity.

Becker, S., Naumann, M., \& Moss, T. (2017). Between coproduction and commons: Understanding initiatives to reclaim urban energy provision in Berlin and Hamburg. Urban Research \& Practice, 10(1), 63-85.

Benford, R. D., \& Snow, D. A. (2000). Framing processes and social movements: An overview and assessment. Annual Review of Sociology, 26, 611-639.

Bilewicz, A. (2015). W strone gospodarki społecznie zanurzonej? Kooperatywy spożywcze w Polsce. (unpublished doctoral thesis).

Bilewicz, A., \& Potkańska, D. (2013). Jak kiełkuje społeczeństwo obywatelskie? Trzeci Sektor, 3(31), 25-44.

Bitusíková, A. (2015). Urban activism in Central and Eastern Europe: A theoretical framework. Slovensky Narodopis, 63(4), 326-338.

Brandsen, T., Steen, T., \& Verschuere, B. (2018). Co-production and co-creation: Engaging citizens in public service delivery. London and New York: Routledge.

Brenner, N., Marcuse, P., \& Mayer, M. (Eds.). (2012). Cities for people, not for profit: Critical urban theory and the right to the city. London: Routledge.

Brenner, N., \& Theodore, N. (2002). Cities and the geographies of 'actually existing neoliberalism'. Antipode, 34(3), 349-379.

Caprotti, F., Cowley, R., Datta, A., Broto, V. C., Gao, E., Georgeson, L., et al. (2017). The New Urban Agenda: Key opportunities and challenges for policy and practice. Urban Research \& Practice, 10(3), 367-378.

Castells, M. (1972). La question urbaine. François Maspero.

Castells, M. (1983). The city and the grassroots: A cross-cultural theory of urban social movements. Berkeley: University of California Press.

Colenbrander, S. (2016). Cities as engines of economic growth: The case for providing basic infrastructure and services in urban areas. IIED Working Paper. IIED, London.

De Souza, M. L. (2010). Which right to which city? In defence of political-strategic clarity. Interface, 2(1), 315-333. 
Della Porta, D. (2015). Social movements in times of austerity: Bringing capitalism back into protest analysis. New York: Wiley.

Di Masso, A. (2012). Grounding citizenship: Toward a political psychology of public space. Political Psychology, 33(1), 123-143.

Diani, M. (1992). The concept of social movement. Sociological Review, 40, 1-25.

Diani, M. (2003). Networks and social movements: A research programme. In M. Diani \& D. McAdam (Eds.), Social movements and networks (pp. 299-318). Oxford/New York: Oxford University Press.

Diani, M. (2015). The cement of civil society: Studying networks in localities. New York: Cambridge University Press.

Diani, M., Ernstson, H., \& Jasny, L. (2018). "Right to the City" and the structure of civic organizational fields: Evidence from Cape Town. VOLUNTAS: International Journal of Voluntary and Nonprofit Organizations. https://doi.org/10.1007/s11266-0189958-1.

Domaradzka, A. (2015). Changing the rules of the game: Impact of the urban movement on the public administration practices. In M. Freise, F. Paulsen, \& A. Walter (Eds.), Civil society and innovative public administration (pp. 188-217). Nomos: Glashütte.

Domaradzka, A. (2016). Leveling the playfield: Urban movement in the strategic action field of urban policy in Poland. In J. Hou \& S. Knierbein (Eds.), City unsilenced: Urban resistance and public space in the age of shrinking democracy. London: Routledge.

Domaradzka, A. (2017). Leveling the playfield: Urban movement in the strategic action field of urban policy in Poland. In J. Hou \& S. Knierbein (Eds.), City unsilenced: Urban resistance and public space in the age of shrinking democracy (pp. 106-118). Routledge.

Domaradzka, A. (2018). The un-equal playground: Developers and urban activists struggling for the right to the city (unpublished)

Domaradzka, A., Jasińska, J., Matysiak, I., \& Żbikowska, A. (2018). Case study report on Food Cooperative "Dobrze". FAB-MOVE project (unpublished)

Domaradzka, A., \& Wijkström, F. (2016). Game of the city renegotiated: The Polish urban re-generation movement as an emerging actor of a strategic action field. Polish Sociological Review, 195, 291.

Earle, L. (2016). Urban crises and the New Urban Agenda. Environment and Urbanization, 28(1), 77-86.

Eide, S. (2016). The disastrous New Urban Agenda, Commentary, 15.06.2016. https://www.commentarymagazine.com/articles/dis astrous-new-urban-agenda/. Accessed 2 August 2018.

Estatuto de la Ciudad de Brasil. (2001). Ley no 10.257, del 10 de Julio de 2001.

Fainstein, N. I., \& Fainstein, S. S. (1974). Urban political movements. Englewood Cliffs, NJ: Prentice-Hall.

Fainstein, S. S., \& Hirst, C. (1995). Urban social movements. In D. Judge, G. Stoker, \& H. Wolman (Eds.), Theories of urban politics (pp. 181-204). London: Sage.

Fincher, R. (1987). Progress Report: Defining and explaining urban social movements. Urban Geography, 8(2), 152-160.

Finnemore, M., \& Sikkink, K. (1998). International norm dynamics and political change. International Organization, 52(4), 887-917.

Flesher Fominaya, C. (2015). Debunking spontaneity: Spain's 15-M/ Indignados as autonomous movement. Social Movement Studies, 14(2), 142-163

Fligstein, N., \& McAdam, D. (2012). A Theory of Fields. New York: Oxford University Press.
Florea, I., Gagyi, A. \& Jacobsson, K. (2018). A field of contention: Evidence from housing struggles in Bucharest and Budapest. VOLUNTAS: International Journal of Voluntary and Nonprofit Organizations. https://doi.org/10.1007/s11266-018-9954-5.

Frantzeskaki, N., Dumitru, A., Anguelovski, I., Avelino, F., Bach, M., Best, B., et al. (2016). Elucidating the changing roles of civil society in urban sustainability transitions. Current Opinion in Environmental Sustainability, 22, 41-50.

Franzén, M. (2005). New social movements and gentrification in Hamburg and Stockholm: A comparative study. Journal of Housing and the Built Environment, 20(1), 51-77.

Freeman, L. (2009). Neighbourhood diversity, metropolitan segregation and gentrification: What are the links in the US? Urban Studies, 46(10), 2079-2101.

Gamson, W. A. (1990). The strategy of social protest. Belmont: Wadsworth Publishing.

Gobo, G. (2016). Glocalization: A critical introduction. European Journal of Cultural and Political Sociology, 3(2-3), 381-385.

Grazioli, M., \& Caciagli, C. (2018). Resisting to the neoliberal urban fabric: Housing rights movements and the re-appropriation of the 'Right to the City' in Rome, Italy. VOLUNTAS: International Journal of Voluntary and Nonprofit Organizations. https://doi. org/10.1007/s11266-018-9977-y.

Gurr, J. M. (2017). All those who know the term 'gentrification' are part of the problem. Resistance: Subjects, Representations, Contexts, 3, 117-134.

Hackworth, J. (2002). Postrecession gentrification in New York city. Urban Affairs Review, 37(6), 815-843.

Hamel, P. (1986). Urban movements in Montréal in the 1980s: Theoretical perspectives and political challenges. Loisir et Société/Society and Leisure, 9(2), 491-508.

Hamel, P. (2014). Urban social movements. In H. A. van der Heijden (Ed.), Handbook of political citizenship and social movements (pp. 464-492). Cheltenham: Edward Elgar.

Hamel, P., Lustiger-Thaler, H., \& Mayer, M. (Eds.). (2000). Urban movements in a globalising world. London: Routledge.

Harris, R. (1987). A social movement in urban politics: A reinterpretation of urban reform in Canada. International Journal of Urban and Regional Research, 11(3), 363-381.

Harvey, D. (1973). Social justice and the city. Oxford: Blackwell.

Harvey, D. (2008). The right to the city. New Left Review, 53, 23-40.

Harvey, D. (2012). Rebel cities. From the right to the city to the urban revolution. New York: Verso.

Holston, J. (1999). Spaces of insurgent citizenship. In J. Holston (Ed.), Cities and citizenship (pp. 155-173). Durham, NC: Duke University Press.

Hou, J., \& Knierbein, S. (2017). City unsilenced. London: Taylor \& Francis Ltd.

İnal, K., \& Gezgin, U. B. (2017). Reclaiming the city, reclaiming the rights. Resistance: Subjects, Representations, Contexts, 3, 101.

Jacobsson, K. (2015). Urban grassroots movements in Central and Eastern Europe. Farnham: Ashgate.

Jacobsson, K., \& Saxonberg, S. (2013). Beyond NGO-ization. The development of social movements in Central and Eastern Europe. Farnham: Ashgate.

Jezierska, K., \& Polanska, D. V. (2017). Social movements seen as radical political actors: The case of the Polish Tenants' movement. VOLUNTAS: International Journal of Voluntary and Nonprofit Organizations. https://doi.org/10.1007/s11266017-9917-2.

Johnson, C. G. (2011). The urban precariat, neoliberalization, and the soft power of humanitarian design. Journal of Developing Societies, 27(3-4), 445-475.

Korolczuk, E. (2011). Problem z ngoizacją. Debata na temat społeczeństwa obywatelskiego w Polsce. Polityka Społeczna, $5-6,37-43$. 
Lawson, R. (1988). The tenant movement in New York City, 1904-1984. New Brunswick, NJ: Rutgers University Press.

Lefebvre, H. (1968). Le Droit à la Ville. Paris: Anthropos.

Lefebvre, H. (1991). The production of space. Oxford: Blackwell.

Lewicka, M. (2011). Place attachment: How far have we come in the last 40 years? Journal of Environmental Psychology, 31, 207-230.

Lorrain, D., \& Stoker, G. (1997). The privatisation of urban services in Europe. London: Routledge.

Marcuse, P. (2009). From critical urban theory to the right to the city. City, 13(2-3), 185-197.

Marcuse, P. (2013). Abandonment, gentrification, and displacement: The linkages in New York City. In N. Smith \& P. Williams (Eds.), Gentrification of the city (pp. 169-193). London: Routledge.

Martin, J. L. (2003). What is field theory? American Journal of Sociology, 109(1), 1-49.

Massam, B. H. (2002). Quality of life: Public planning and private living. Progress in planning, 58(3), 141-227.

Massey, D. (1994). Space, place and gender. Oxford: Polity Press.

Mayer, M. (2007). Contesting the neoliberalization of urban governance. In H. Leitner, J. Peck, \& E. Sheppard (Eds.), Contesting neoliberalism: The urban frontier. New York: Guilford Press.

Mayer, M. (2009). The 'right to the city' in the context of shifting mottos of urban social movements. City, 13(2-3), 362-374.

Mayer, M., \& Boudreau, J. A. (2012). Social movements in urban politics: trends in research and practice. In K. Mossberger, S. E. Clarke, \& P. John (Eds.), Oxford handbook on urban politics (pp. 273-291). Oxford: Oxford University Press.

Mayer, M., Thörn, H., \& Thörn, C. (Eds.). (2016). Urban uprisings: Challenging neoliberal urbanism in Europe. London: Palgrave Macmillan.

McAdam, D., McCarthy, J. D., \& Zald, M. N. (Eds.). (2004). Comparative perspectives on social movements: Political opportunities, mobilizing structures and cultural framings. Cambridge: Cambridge University Press.

Mergler, L. (2008). Poznań Konfliktów. Poznań: Wydawnictwo Lepszy Świat.

Mergler, L., Pobłocki, K., \& Wudarski, M. (2013). Anty-bezradnik przestrzenny: prawo do miasta $w$ dziataniu. Warszawa: Res Publika Nowa.

Meyrowitz, J. (2005). The rise of glocality: New senses of place and identity in the global village. In K. Nyíri (Ed.), A sense of place: The global and the local in mobile communication (pp. 21-30). Vienna: Passagen.

Mitscherlich, A. (1965). Die Unwirtlichkeit unser Städte: Anstiftung zum Unfrieden (Our Inhospitable Cities: An Incitement to Unrest). Frankfurt: Suhrkamp.

Nawratek, K. (2012). Holes in the whole: Introduction to the urban revolutions. Winchester: Zero Books.

Nawratek, K. (Ed.). (2017). Urban re-industrialization. Brooklyn: Punctum Books.

New Urban Agenda. (2016). UN-HABITAT. http://habitat3.org/wpcontent/uploads/NUA-English.pdf. Accessed 4 Aug 2018.

Novy, J., \& Colomb, C. (2013). Struggling for the right to the (creative) city in Berlin and Hamburg: New urban social movements, new 'spaces of hope'? International Journal of Urban and Regional Research, 37, 1816-1838.

Offe, C. (1985). New social movements: Challenging the boundaries of institutional politics. Social Research, 52, 817-868.

Olives, J. (1972). La lutte contra la rénovation urbaine dans le quartier de «la cité d'Aliarte» (Paris). Espaces et sociétés, 6-7.

Özdemir, E., \& Eraydin, A. (2017). Fragmentation in urban movements: The role of urban planning processes. International Journal of Urban and Regional Research, 41(5), 727-748.
Pickvance, C. (Ed.). (2003). Symposium on urban movements. International Journal of Urban and Regional Research, 27, 102-177

Pluciński, P. (2018). Forces of altermodernization: Urban social movements and the new urban question in contemporary Poland. VOLUNTAS: International Journal of Voluntary and Nonprofit Organizations. https://doi.org/10.1007/s11266-018-0007-x.

Polanska, D. V. (2011). The emergence of enclaves of wealth and poverty. A sociological study of residential differentiation in post-communist Poland. Stockholm: Acta Universitatis Stockholmiensis.

Polish Urban Policy. (2014). Ministry of Infrastructure and Development. http://www.mir.gov.pl/fundusze/Fundusze_Europejskie_ 2014_2020/Documents/Krajowa_Polityka_Miejska_wersja_I_27 032014.pdf. Accessed 4 Aug 2018.

Pruijt, H. (2007). Urban movements. In G. Ritzer (Ed.), Blackwell encyclopedia of sociology (pp. 5115-5119). Malden: Blackwell.

Purcell, M. (2003). Citizenship and the right to the global city: Reimagining the capitalist world order. International Journal of Urban and Regional Research, 27(3), 564-590.

Ranci, C., Brandsen, T., \& Sabatinelli, S. (Eds.). (2014). Social vulnerability in European cities: The role of local welfare in times of crisis. Berlin: Springer.

Robertson, R. (1992). Globalization: Social theory and global culture. London: Sage.

Sahlin, K., \& Wedlin, L. (2008). Circulating ideas: Imitation, translation and editing. In R. Royston Greenwood, C. Oliver, R. Suddaby, \& K. Sahlin (Eds.), The SAGE handbook of organizational institutionalism. New York: SAGE.

Santos, F. (2018). Caring for housing rights: How the platform of those affected by mortgages managed to confront evictions in Spain (paper presented at the doctoral conference at CEU, March 21st, 2018).

Sassen, S. (1996). Whose city is it? Globalization and the Formation of New Claims. Public Culture, 8, 205-223.

Sassen, S. (Ed.). (2002). Global networks, linked cities. Hove: Psychology Press.

Sava, I. N. (2015). Social movements in Central and Eastern Europe: A renewal of protests and democracy. Bucureşti: Editura Universităţii din Bucureşti.

Schreier, C. (Ed.). (2016). 25 years after: Mapping civil society in the Visegrád Countries (Vol. 11). Berlin: Walter de Gruyter GmbH \& Co KG.

Simmel, G. (1903). The metropolis and mental life. In G. Bridge \& S. Watson (Eds.), The Blackwell city reader. Oxford and Malden, MA: Wiley-Blackwell.

Sinha, A., \& Kasdan, A. (2013). Inserting community perspective research into public housing policy discourse: The Right to the City Alliance's "We Call These Projects Home". Cities, 35, 327-334.

Smith, N. (1987). Gentrification and the rent gap. Annals of the Association of American Geographers, 77(3), 462-465.

Smith, S. (1995). Citizenship: All or nothing? Political Geography, 14(2), 190-193.

Smith, N. (2008). Uneven development: Nature, capital and the production of space (3rd ed.). Oxford: Blackwell.

Soja, E. W. (2010). Seeking spatial justice. Minneapolis: University of Minnesota Press.

Staeheli, L. (2003). Cities and citizenship. Urban Geography, 24(2), 97-103.

Strang, D., \& Soule, S. (1998). Diffusion in organizations and social movements: From hybrid corns to poison pills. Annual Review of Sociology, 24, 265-290.

Swyngedouw, E. (1997). Excluding the other: the contested production of a new "Gestalt of Scale" and the politics of marginalisation. In R. Lee \& J. Wills (Eds.), Society, place, economy: 
States of the art in economic geography. London: Edward Arnold.

Tasan-Kok, T., van Kempen, R., Raco, M., \& Bolt, G. (2014). Towards hyper-diversified european cities. A critical literature review. Utrecht: Utrecht University.

Thörn, H. (2012). In between social engineering and gentrification: Urban restructuring, social movements, and the place politics of open space. Journal of Urban Affairs, 34(2), 153-168.

Tilly, C. (1978). From mobilization to revolution. New York: Random House.

Uitermark, J. (2004). The co-optation of squatters in Amsterdam and the emergence of a movement meritocracy: A critical reply to Pruijt. International Journal of Urban and Regional Research, 28(3), 687-698.

UNESCO. (2006). International public debates: urban policies and the right to the city. Paris: UNESCO.
Urban Agenda for the EU. (2016). European Commission, Brussels. http://ec.europa.eu/regional_policy/en/policy/themes/urban-deve lopment/agenda/. Accessed 4 Aug 2018.

Vliet, W. V. (2002). Cities in a globalizing world: From engines of growth to agents of change. Environment and Urbanization, 14(1), 31-40.

Vogel, R., \& Savitch, H. V. (2012). New state spaces, globalization, and the politics of rescaling. Paper presented at the Governing the Metropolis: Powers and Territories, Paris, 29 November.

Wallerstein, I. M. (2004). World-systems analysis: An introduction. Durham: Duke University Press.

Zabłocka-Bursa, A., \& Praszkier, R. (2012). Social change initiated by social entrepreneurs. In A. Nowak, D. Bree, \& K. Winkowska-Nowak (Eds.), Complex human dynamics. From minds to societies (pp. 153-170). New York: Springer. 